\title{
Household Arrangements of the Elder Elderly
}

\author{
Elizandra Cristina Pedrazzi ${ }^{1}$ \\ Talita Tavares Della Motta ${ }^{2}$ \\ Thaís Ramos Pereira Vendrúscolo ${ }^{3}$ \\ Suzele Cristina Coelho Fabrício-Wehbe ${ }^{4}$ \\ Idiane Rosset Cruz ${ }^{4}$ \\ Rosalina Aparecida Partezani Rodrigues ${ }^{5}$
}

The aging context of the elder elderly needs to be taken into account, due to the redefinition of family as a social institution. This is an epidemiological, cross-sectional study that characterized the household arrangements of 147 elder elderly living in Ribeirão Preto, $\mathrm{SP}$, through home interviews. The age range between 80 and 84 years predominated. The majority receives a retirement benefit ranging from one to three minimum wages, and owns their house. On the average, they have 4.08 children and live with 2.8 people. Most men live with their partners, while women live by themselves. The elderly head a large part of households. The most frequent arrangements are families with two and three generations. Regarding the household arrangement, there was equivalence in the results between the ones that moved into the house of the elderly and cases when the elderly moved into the family's house, reinforcing the family as a protector and caregiver of the elderly.

Descriptors: Aged; Family; Gerontology.

Escola de Enfermagem de Ribeirão Preto, Univesidade de São Paulo, WHO Collaborating Centre for Nursing Research Development, Brazil:

${ }^{1}$ RN, M.Sc. in Nursing, e-mail: elizandra_p@yahoo.com.br.

${ }^{2}$ Nursing undergraduate student, e-mail: tata.dellamotta@hotmail.com.

${ }^{3} \mathrm{RN}$, CNPq grantholder - technical support, e-mail: thaisvendruscolo@yahoo.com.br.

${ }^{5}$ RN, Full Professor, e-mail: rosalina@eerp.usp.br.

Escola de Enfermagem and Escola de Enfermagem de Ribeirão Preto, Univesidade de São Paulo:

${ }^{4}$ RN, Doctoral Student, e-mail: suzelecris@ig.com.br, rossetidi@hotmail.com.

Corresponding Author:

Rosalina Aparecida Partezani Rodrigues

Escola de Enfermagem de Ribeirão Preto. Universidade de São Paulo

Av. dos Bandeirantes, 3900

Bairro Monte Alegre

CEP: 14040-02 Ribeirão Preto, SP, Brazil

E-mail: rosalina@eerp.usp.br 


\section{Arranjo domiciliar dos idosos mais velhos}

O contexto do envelhecimento dos idosos mais velhos necessita ser considerado em decorrência da redefinição da família como instituição social. Este é estudo epidemiológico, transversal, que caracterizou o arranjo domiciliar de 147 idosos mais velhos residentes na comunidade de Ribeirão Preto, SP, através de entrevistas domiciliares. Predominou a faixa etária de 80 a 84 anos. A maioria recebe aposentadoria, possui de um a três salários mínimos, mora em casa própria. Possui 4,08 filhos e reside com 2,8 pessoas, em média. Os homens vivem, na maioria, com o cônjuge, enquanto as mulheres, sozinhas, e os domicílios são chefiados pelo idoso. Os arranjos mais continentes foram os bi e trigeracionais. Quanto à formação do arranjo domiciliar, houve equivalência nos resultados entre aqueles que afirmaram ter ido morar com o idoso e aqueles em que o idoso foi morar no domicílio da família, o que reforça a família como protetora e cuidadora dos idosos.

Descritores: Idoso; Família; Gerontologia.

\section{Arreglo domiciliar de los ancianos de edad avanzada}

El contexto del envejecimiento de ancianos con edad avanzada necesita ser considerado como una consecuencia de la redefinición de la familia como institución social. Este es un estudio epidemiológico, transversal, que caracterizó el arreglo domiciliar de 147 ancianos con edad avanzada residentes en la comunidad de Ribeirao Preto, Sao Paulo, Brasil, a través de entrevistas domiciliares. Predominó el intervalo de edad de 80 a 84 años. La mayoría era jubilado, recibía de un a tres salarios mínimos y habitaba en casa propia. Tenían 4,08 hijos y vivían con 2,8 personas, en promedio. Los hombres vivían, en su mayoría, con el conyugue, en cuanto las mujeres, lo hacían solas, y los domicilios eran dirigidos por el anciano. Los arreglos más convenientes fueron los realizados con la segunda y tercera generaciones. En cuanto a la formación del arreglo domiciliar, hubo equivalencia en los resultados, entre aquellos que afirmaron haber ido a vivir con el anciano y aquellos en que el anciano fue a vivir en el domicilio de la familia, lo que refuerza la familia como protectora y cuidadora de los ancianos.

Descriptores: Anciano; Família; Gerontología.

\section{Introduction}

Population aging is a global phenomenon today. This means that the elderly population, older than 60 years, grows at a more accelerated pace than other age groups. Besides, the proportion of elderly aged 80 years or older is also increasing, that is, the population that is considered old is also aging ${ }^{(1)}$

In 2008, there were 67,965 elderly in Ribeirão Preto, $54 \%$ of whom were between 60 and 69 years old, $31.3 \%$ between 70 and 79 years old and $14.5 \%$ older than 80 years. The estimated population for 2009 was 70,677 elderly, $14.7 \%$ of whom would be 80 years or older $^{(2)}$. In parallel with this increase in life expectancy, as from the 1960 's, a marked decline of fecundity has been observed. According to a demographic study by the Brazilian Institute of Geography and Statistics (IBGE) (3), more and more, families are having less children: in 1960, the mean number of children per woman was six, against 2.39 in 2000, with an estimated 1.5 children per woman as the borderline Brazilian fecundity around 2028.

Population aging entails important implications for the elderly people's social protection. The growing number of divorces, multiple marriages, migration of younger people in search of more promising markets, women's insertion in the job market and their role as family heads all need to be taken into account when assessing household arrangements and informal support to the 
elderly in the Brazilian society ${ }^{(1)}$. Moreover, socioeconomic modifications in Latin American countries have returned many children to their parents' home, besides the fact that they remain economically dependent longer ${ }^{(4)}$.

A study on the social network and health of elderly people in three different society, one Latin American (Costa Rica), one Latin-European (Spain), and another Anglo-Saxon (United Kingdom) showed distinct models of family networks in those countries(5). Costa Rica is characterized by inter-generational co-residency, while the British family network model reflects aged people's great independence and social support is transmitted through non-family networks. The Spanish society, then, shows an intermediary family network model, based on co-residency but going through a transition phase. Costa Rica presented stronger family support networks than European societies. In that society, less than $10 \%$ of the elderly live alone, against $33 \%$ of the British and $23 \%$ of the Spanish elderly(5).

Co-residency with the elderly mainly occurs when they are in greater need, like when their health state worsens or their partner passes away. In China, changes in elder elderly people's household arrangements are frequent and more related to functional limitations than to other health indicators ${ }^{(6)}$.

However, few studies were found in Brazilian and international literature which assessed the family support network of elderly living in the community, mainly elder elderly.

Based on these data, planning proposals can be elaborated to respond to this elderly population group's care needs, which has considerably grown in the Brazilian society. In this perspective, homes are a unique place to offer nurses the opportunity to observe how people face health/disease situations in their family core, as well as available resources. In order to actually support, favor and sustain a care system, however, further understanding is needed about relevant interrelations in households and families.

\section{Aim}

To characterize the elder elderly according to socioeconomic and demographic characteristics and describe their household arrangements according to the type of arrangement, the family head, education and reasons for housing.

\section{Method}

This study was carried out in the urban region of Ribeirão Preto, SP, through home interviews with elder elderly people living in the community. It is a populationbased epidemiological and cross-sectional research, using a representative sample of 147 elderly aged 80 years or older, calculated on the estimated population for 2004. This research is part of a broader project called "Living and Health Conditions of Elderly People in Ribeirão Preto (SP)", which uses a probabilistic sample of elderly aged 65 years or older. Approval was obtained from the Research Ethics Committee at the University of São Paulo at Ribeirão Preto College of Nursing.

A probabilistic, double-stage cluster sampling process was applied. In the first stage, 30 census sectors were drafted from the 600 sectors in the city. The second stage was a draft with a fixed number of homes, resulting in a self-weighted sample.

The responsible researcher elaborated the free and informed consent term and the elderly received one copy, in compliance with Brazilian standards. For data collection, a questionnaire was used with the subjects' identification, socio-demographic characterization and social profile. The variables to examine the elderly people's household arrangement were selected from the data collection questionnaire of the SABE research - Health, Well-being and Aging in Latin America and the

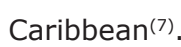

Family arrangements were subdivided into the following groups: the elderly lives alone; lives with the partner only; lives with the partner and children; lives with the partner, children, son or daughter-in-law; lives with the children only; three-generational arrangements, i.e. live with the children and grandchildren: lives with the grandchildren only (without the children); and the elderly lives with non-relatives ${ }^{(7)}$.

The database was elaborated in Excel software and information was subject to VALIDATE. SPSS (Statistical Package for Social Science) for Windows was used for statistical analyses. Variables were described through frequency measures, mean, median, standard deviation and variables considered as independent (social and demographic). Associations were measured through Mann-Whitney's non-parametrical tests and Spearman's coefficient, considering a 5\% significance level. 


\section{Results}

In total, 147 home interviews were held with elderly aged 80 years or older.

Table 1 - Frequency distribution of demographic and socioeconomic variables according to gender of elder elderly in Ribeirão Preto, 2008

\begin{tabular}{|c|c|c|c|}
\hline \multirow{2}{*}{ Variables } & \multicolumn{3}{|c|}{ Gender $(n=147)$} \\
\hline & Female $n(\%)$ & Male n (\%) & Total n (\%) \\
\hline \multicolumn{4}{|l|}{ Age (full years) } \\
\hline $80-84$ & $60(64.5)$ & $33(35.5)$ & $93(63.3)$ \\
\hline $85-89$ & $27(67.5)$ & $13(32.5)$ & $40(27.2)$ \\
\hline 90 or + & $11(78.6)$ & $3(21.4)$ & $14(9.5)$ \\
\hline \multicolumn{4}{|l|}{ Civil status } \\
\hline Single & $7(77.8)$ & $2(22.2)$ & $9(6.1)$ \\
\hline Married & $16(30.2)$ & $37(69.8)$ & $53(36.1)$ \\
\hline Divorced/separated & $2(40.0)$ & $3(60.0)$ & $5(3.4)$ \\
\hline Widowed & $73(91.3)$ & $7(8.8)$ & $80(54.4)$ \\
\hline \multicolumn{4}{|l|}{ Education (years) } \\
\hline Illiterate & $30(83.3)$ & $6(16.7)$ & $36(24.5)$ \\
\hline 1 to 4 & $50(58.8)$ & $35(41.2)$ & $85(57.8)$ \\
\hline 5 to 8 & $7(77.8)$ & $2(22.2)$ & $9(6.1)$ \\
\hline 9 to 12 & $6(66.7)$ & $3(33.3)$ & $9(6.1)$ \\
\hline $13+$ & $5(62.5)$ & $3(37.5)$ & $8(5.4)$ \\
\hline \multicolumn{4}{|l|}{ Income } \\
\hline Retirement benefit & $36(42.4)$ & $49(57.6)$ & $85(57.8)$ \\
\hline Pension & $59(96.7)$ & $2(3.3)$ & $61(41.5)$ \\
\hline Rent & $11(68.8)$ & $5(31.3)$ & $16(10.9)$ \\
\hline Own work & $3(42.9)$ & $4(57.1)$ & $7(4.8)$ \\
\hline Donations & $14(63.6)$ & $8(36.4)$ & $22(15)$ \\
\hline Others & $5(83.3)$ & $1(16.7)$ & $6(4.1)$ \\
\hline \multicolumn{4}{|l|}{ Income (minimum wages) } \\
\hline 0 & $9(100.0)$ & $0(0.0)$ & $9(6.1)$ \\
\hline Up to 1 & $2(66.7)$ & $1(33.3)$ & $3(2.0)$ \\
\hline 1 to 3 & $75(70.8)$ & $31(29.2)$ & $106(72.1)$ \\
\hline+3 & $12(41.4)$ & $17(58.6)$ & $29(19.7)$ \\
\hline \multicolumn{4}{|l|}{ Type of housing } \\
\hline Own - fully paid & $66(60.6)$ & $43(39.4)$ & $109(74.1)$ \\
\hline Pays rent & $10(76.9)$ & $3(23.1)$ & $13(8.8)$ \\
\hline $\begin{array}{l}\text { Own - pays } \\
\text { installments }\end{array}$ & $4(100.0)$ & $0(0.0)$ & $4(2.7)$ \\
\hline Ceded without rent & $15(88.2)$ & $2(11.8)$ & $17(11.6)$ \\
\hline Other & $3(75.0)$ & $1(25.0)$ & $4(2.7)$ \\
\hline
\end{tabular}

Table 1 shows data for the elderly participants' socioeconomic and demographic characteristics. The mean age was 84.1 years, the median 83 , and the standard deviation 4.0. When comparing age between men and women, the Mann-Whitney test showed that differences are not statistically significant $(p=0.650)$. The age of male elderly ranged from 80 to 93 years and that of female elderly from 80 to 103 years. In the gender distribution, there are more female than male elderly in all age ranges.

As to civil status, widows predominate among women, while married elderly are mostly men. Years of education range from zero to eighteen, with a mean 3.6 years and concentration in the group with between one and four years of study. According to Mann-Whitney's test, differences were not statistically significant $(p=0.195)$ in the analysis between gender and education. Nevertheless, higher frequencies of illiteracy prevailed among women. Most elderly were white, lived in their own house and received a retirement benefit, predominantly men. The second source of income was a pension, particularly among women.

Most participants received between one and three minimum wages (MW), and a small percentage more than three minimum wages, as shown in Table 1 . The elderly people's mean income was $R \$ 955.70$, the median R\$ 440.00 and standard deviation $\mathrm{R} \$$ 1341.80. Female elderly participants' mean income was $\mathrm{R} \$$ 722.60, against $\mathrm{R} \$ 1421.80$ for men. The Mann-Whitney test showed that gender differences in income are statistically significant $(p=0.002)$. The elderly people's family income is concentrated between one and three MW (36.7\%) and more than three MW $(37.4 \%)$. Only ten elderly indicated one MW as the family income.

As for the number of children, $42.9 \%$ of the elderly have between three and five children, 29.3\% between one and two and $19.7 \%$ six children or more, with a mean 4.08 children, while $8.2 \%$ declared they had no children. Between one and twelve people live at their house, with a mean 2.8 people.

Among the elderly who affirmed a family income of one MW, a majority (60\%) lives with two people. As the family income increases, so does the number of people living at the house. Among participants gaining one to three MW, $40.7 \%$ live with two people, $35.2 \%$ with three to five people and $9.3 \%$ with more than six people. When the family income exceeds more than three MW, the situation is equivalent, but a majority lives with three to five people. 
Table 2 - Frequency distribution of variables characterizing household arrangement, according to gender of elder elderly. Ribeirão Preto, 2008.

\begin{tabular}{|c|c|c|c|}
\hline \multirow{2}{*}{ Variables } & \multicolumn{3}{|c|}{ Gender $(n=147)$} \\
\hline & Female n (\%) & Male n (\%) & Total n (\%) \\
\hline \multicolumn{4}{|l|}{ Whom they live with } \\
\hline Alone & $15(71.4)$ & $6(28.6)$ & $21(14.3)$ \\
\hline With partner only & $12(30.8)$ & $27(69.2)$ & $39(26.5)$ \\
\hline Partner and child(ren) & $1(16.7)$ & $5(83.3)$ & $6(4.1)$ \\
\hline Partner, children, son or daughter-in-law & $0(0.0)$ & $2(100.0)$ & $2(1.4)$ \\
\hline With child(ren) only & $20(95.2)$ & $1(4.8)$ & $21(14.3)$ \\
\hline Three-generational arrangement (elderly, children and grandchildren) & $15(93.8)$ & $1(6.3)$ & $16(10.9)$ \\
\hline Intra-generational arrangements (with other elderly only) & $5(71.4)$ & $2(28.6)$ & $7(4.8)$ \\
\hline With grandchildren only (without children) & $2(66.7)$ & $1(33.3)$ & $3(2.0)$ \\
\hline Non relatives & $4(100.0)$ & $0(0.0)$ & $4(2.7)$ \\
\hline Others & $24(85.7)$ & $4(14.3)$ & $28(19)$ \\
\hline \multicolumn{4}{|l|}{ Who is the head } \\
\hline Elderly & $40(47.6)$ & $44(52.4)$ & $84(57.1)$ \\
\hline Partner & $13(92.9)$ & $1(7.1)$ & $14(9.5)$ \\
\hline Son/daughter & $23(92.0)$ & $2(8.0)$ & $25(17)$ \\
\hline Other relative & $20(90.9)$ & $2(9.1)$ & $22(15)$ \\
\hline Non relative & $2(100.0)$ & $0(0.0)$ & $2(1.4)$ \\
\hline \multicolumn{4}{|l|}{ Establishment of arrangement } \\
\hline Elderly moved into the house & $28(90.3)$ & $3(9.7)$ & $31(21.1)$ \\
\hline Others moved into the elderly's house & $28(75.7)$ & $9(24.3)$ & $37(25.2)$ \\
\hline Other & $42(53.2)$ & $37(46.8)$ & $79(53.7)$ \\
\hline \multicolumn{4}{|l|}{ Reason for living in the house } \\
\hline Being close to or with child(ren)/parents & $10(83.3)$ & $2(16.7)$ & $12(8.2)$ \\
\hline Being close to or with relatives or friends & $6(100.0)$ & $0(0.0)$ & $6(4.1)$ \\
\hline Death of husband/wife or partner & $30(88.2)$ & $4(11.8)$ & $34(23.1)$ \\
\hline Marital union & $13(31.7)$ & $28(68.3)$ & $41(27.9)$ \\
\hline Marital separation & $9(64.3)$ & $5(35.7)$ & $14(9.5)$ \\
\hline Housing cost/financial situation & $3(75.0)$ & $1(25.0)$ & $4(2.7)$ \\
\hline Needed care & $8(88.9)$ & $1(11.1)$ & $9(6.1)$ \\
\hline Other & $19(70.4)$ & $8(29.6)$ & $27(18.4)$ \\
\hline
\end{tabular}

Table 2 evidences information about elder elderly people's household arrangements in Ribeirão Preto, and that most of them live with their partner. Another large group lives alone and with their children. Women living alone predominate, as well as men living with their partner. Most women live with their children only. More than half of the elderly are family heads, and this number is equivalent between men and women.

Results for how the household arrangement was established were equivalent too, between family members who had gone to live with the elderly and elderly people who had gone to live at the family's home. The "others" alternative received many answers, which can be explained by the large number of couples, children who had always lived with their parents and were still living at their home, besides elderly living alone. With regard to the reasons for living at the house, most participants mentioned it was due to the marital union, followed by those who indicated the partner's death as the motive for the current arrangement. The need for care or the elderly people's financial situation was not mentioned as a reason.

Exploring the study data, some relations could be established between the variables. In the relation between the household arrangement and the marital state, it was observed that single elderly tend to live in intra-generational arrangements (44.4\%). Divorced elderly live alone (40\%) and in three-generational arrangements (40\%) and widowed participants mostly live with their children (26.3\%), alone (23.8\%) and in other arrangements (22.5\%). When analyzing the relation between the household arrangement, gender and age, a majority (32.3\%) of male elderly (57.6\%) between 80 and 84 years of age live with their partner, while $16.1 \%$ live alone, mostly women (18.3\%); $11.8 \%$ with children and $10.8 \%$ with children and grandchildren. Among elderly between 85 and 89 years of age, the number of elderly living alone (10\%) and with their partner $(20 \%)$ is quite low and the relation between the genders is the same as mentioned above. Elderly 
people living with their children represent $17.5 \%$. The predominant arrangements in the age range above 90 years were of people living with their children, and with their children and grandchildren (21.4\%). The relation established between family head, gender and marital status showed that female elderly are predominant as family heads when they are widowed (90\%), and male elderly when they are married (81.8\%).

As to the reason for setting up the arrangement, for elderly who went to live with other people, $25 \%$ live with their children only or in three-generational arrangements so as to be close to their children, $15.4 \%$ mentioned widowhood and, for $50 \%$, the reason was separation. The same reason was responsible for $50 \%$ of intragenerational arrangements. For half of the elderly who received non-relatives in their home, the justification was to be close to relatives or friends. One motive mentioned by people who went to live with the elderly, constituting a three-generational arrangement, was the death of the partner (75\%). $33.3 \%$ of the interviewees mentioned marital union as the reason for setting up the arrangement "partner, child, son or daughter-in-law". Separation made children live with their parents $(11.1 \%)$ or with one of their parents $(22.2 \%)$ and in threegenerational arrangements (33.3\%). Care needs made people live with the elderly in "partner, children, son or daughter-in-law" arrangements, intra-generational (20\%) and non-family arrangements (40\%).

\section{Discussion}

The femininization of aging is a current situation in which the absolute number of female elderly has been higher when compared with that of men aged 65 years and older. This fact derives from the distinguished mortality situation prevailing since 1950, with a life expectancy six years longer for women ${ }^{(8)}$. Studies with Brazilian elderly aged 80 years or older have found a high prevalence of widowed people, mainly women, and a larger number of married people among men ${ }^{(9-10)}$. In São Paulo, the prevalence of widowed people was about $45 \%{ }^{(9)}$, against $62 \%$ in the rural context of Rio Grande do Sul(10). These data indicate the importance of readapting to a new family arrangement in this age range.

About years of education, studies report high frequencies of illiteracy in the elderly population, with $40 \%$ of elderly men and $48 \%$ of women declaring themselves illiterate between 1950 and $1993^{(8)}$. Besides, $58.8 \%$ of elder elderly in rural Rio Grande do Sul were illiterate and male elderly obtained the best education levels, supporting data from the present research ${ }^{(10)}$. Another research on octogenarians, carried out in the interior of São Paulo State, showed very similar results with regard to age, education, family income and civil status frequencies of the elder elderly(9).

As for economic conditions, in the year 2000, $77 \%$ of elderly Brazilian women were receiving some social insurance benefit, which favored $94 \%$ of widows ${ }^{(11)}$, a fact that provides greater financial independence to live alone, according to a research in the United States ${ }^{(12)}$. Gaining an income favors active aging, as it contributes to the family budget, grants financial autonomy to see to the elderly people's needs and exerts considerable weight in the revenues of families with elderly members ${ }^{(1)}$. One research calls attention to the proportion of poor families with elderly members, lower when compared to families without elderly ${ }^{(1)}$. Many elderly people still live alone. A research carried out by the United Nations Organization (UN) analyzed the household arrangements of the aged, presenting comparative data for 130 countries, and concluded that approximately one in every seven elderly people (90 million) lives alone, about $2 / 3$ of whom are women; there is a more consolidated trend towards independent modes of living (alone or alone with the partner) in developed countries; the proportion of married elderly women is smaller when compared to men (about $45 \%$ against $80 \%$ ); although the most common arrangement is to live apart from the children in developed countries, in developing countries, most elderly live with their children(13). In Brazil, the proportion of elder elderly living alone is $21.3 \%{ }^{(7)}$. The universal coverage of social security, improved health conditions and advances in communication means, transportation and services can suggest that, for the elderly, living alone represents an innovative and highly successful form of aging, instead of abandonment and solitude ${ }^{(4)}$.

A study on household arrangements in Latin America and the Caribbean showed that bi-generational arrangements predominated, followed by couples. This type of arrangement stands out due to the fact that the ages of couples are near, suggesting that they can serve as caregivers for other elderly people. In threegenerational arrangements, there is a larger number of co-residents and a greater potential for help ${ }^{(7)}$, supporting the research results.

Co-residency benefits both the elderly and the younger generations ${ }^{(4)}$. The need for physical, affective or financial help makes many elderly cease to live independently to go and live with their families.

Elderly people do not necessarily want to live with 
their relatives. In a research on Mexican elderly female family heads, the authors found that more than $2 / 3$ of them would prefer to continue living in their own homes in old age, $11 \%$ of whom would choose to live alone. When asked about their preference to live alone, the elderly women showed their concern with their own privacy and that of their relatives ${ }^{(14)}$.

Families headed by women, due to the absence of a husband/partner, indicate greater difficulties due to a smaller income and more health problems ${ }^{(15)}$. Discussing IBGE data on family heads for the period from 1983 to 2003 , it is remarkable that most male elderly head their families (90\%) and that this condition did not change over the years. Among female elderly, on the other hand, married women prevailed(11).

With regard to the data, arrangements headed by children and other relatives were mostly appeared in reports of female elderly. The elderly participants' dependence on the family should be highlighted, measured based on the relation with the family head as a "relative" or "aggregate", i.e. parents or fathers-in-law who, due to the lack of income or physical or mental autonomy, go and live with children or other relatives(4). In the analysis of SABE project data for São Paulo, Buenos Aires, Montevideo and Mexico City, the author observed that the probability of receiving functional help among elderly people living alone is $63 \%$ lower than for people living with another person. Moreover, cohabiting tends to significantly increase the flow of financial help ${ }^{(7)}$.
With regard to the flow that led to the establishment of the household arrangement, physical, economic or psychological dependence only start to increase at the age of 80 years, with the need for the family to live with the elderly or vice-versa, favoring younger and older generations. At that moment, the family concept should be broadened to cover the elderly people's demands, including neighbors and health professionals from the services the elderly is covered by ${ }^{(15)}$.

\section{Final Considerations}

In Ribeirão Preto, further investments are needed in governmental and non-governmental programs, considering increased longevity, the decreased number of family members and the large group of elderly people living alone. Projects are needed that are articulated between the social and health areas, so as to support elder elderly and their families, in view of the need for health care. Both health and educational entities should participate to put these projects in practice in Ribeirão Preto, assuming their responsibility for inhabitants, families and society in general. Health professionals should get specialized knowledge on gerontology and geriatrics, and nurses should be involved in multiprofessional teams. Moreover, nowadays, it is observed that the health area is responding to family health care policies, acknowledging this as a need and opportunity to develop nursing work for this new and growing part of the population, which is considered as fragile.

\section{References}

1. Camarano AA, Kanso S, Mello JL. Como vive o idoso brasileiro? In: Camarano AA. (org). Muito além dos 60: os novos idosos brasileiros. Rio de Janeiro: IPEA; 2004.

2. Ministério da Saúde (BR). Censos Demográficos e Contagem Populacional para os anos intercensitários, estimativas preliminares dos totais populacionais, estratificadas por idade e sexo, 2008 e 2009. [Acesso em: 20 abril 2009]. Disponível em: URL: http://tabnet.datasus.gov.br/cgi/tabcgi.exe?ibge/ cnv/popsp.def

3. Instituto Brasileiro de Geografia e Estatística (IBGE). Projeção da População do Brasil por Sexo e Idade (1980-2050): Revisão 2008. Rio de Janeiro; 2008.

4. Camarano AA, Kanso S, Mello JL, Pasinato MT. Famílias: espaço de compartilhamento de recursos e vulnerabilidades. In: Camarano AA, organizador. Muito além dos 60: os novos idosos brasileiros. Rio de Janeiro: IPEA; 2004. p. 137-67.

5. Puga D, Rosero-Bixby L, Glaser K, Castro T. Red social y salud del adulto mayor en perspectiva comparada: Costa Rica, España e Inglaterra. Población y Salud en Mesoamérica 2007; 5(1): artículo 1.

6. Zimmer Z. Health and Living Arrangement
Transitions Among China's Oldest-Old Zimmer Res on Aging 2005; 27:526-55.

7. Lebrão ML, Duarte YAO. SABE - Saúde, Bem-estar e Envelhecimento - O Projeto SABE no município de São Paulo: uma abordagem inicial. Brasília: Organização Pan - americana da Saúde; 2003.

8. Berquó E. Algumas considerações demográficas sobre o envelhecimento da população no Brasil. In: Anais do I Seminário Internacional - Envelhecimento Populacional. Brasília: MPAS; 1996. p. 16-34.

9. Inouye K, Pedrazzani ES. Instruction, social economic status and evaluation of some dimensions of octogenarians' quality of life. Rev Latino-am Enfermagem 2007 setembro-outubro; 15(spe):742-7.

10. Morais EP. Envelhecimento no meio rural: condições de vida, saúde e apoio dos idosos mais velhos de Encruzilhada do Sul - RS. [Doutorado em Enfermagem Fundamental]. Ribeirão Preto (SP): Escola de Enfermagem de Ribeirão Preto/USP; 2007.

11. Camarano AA. Mulher idosa: suporte familiar ou agente de mudança? Estudos Avançados USP 2003; 17(49):35-63. 
12. Mcgarry K, Schoeni RF. Social security, economic growth, and the rise in elderly widow's independence in the twentieth century. Demography 2000 May; 37(2):221-36.

13. United Nations. Living arrangements of older persons around the world. New York: United Nations; 2005.

14. Varley A, Blasco M. ¿Cosechan lo que siembran? Mujeres ancianas, vivienda y relaciones familiares en el México urbano.
In: Gomes C. (Comp). Procesos sociales, población y familia: alternativas teóricas y empíricas en las investigaciones sobre vida doméstica. México: Facultad Latinoamericana de Ciencias Sociales; 2001. p. 301-23.

15. Silva MJ, Bessa MEP, Oliveira AMC. Tamanho e estrutura familiar de idosos residentes em área periférica de uma metrópole. Cienc. Enferm 2004 junho; 10(1):31-9.

Received: Oct. $10^{\text {th }} 2008$

Accepted: Sep. $3^{\text {rd }} 2009$ 